\title{
Quantification of bottom trawl fishing damage to ancient shipwreck sites
}

\author{
Michael L. Brennan*1,2, Dan Davis ${ }^{3}$, Robert D. Ballard ${ }^{1,2}$, Arthur C. Trembanis ${ }^{4}$, J. Ian Vaughn ${ }^{5}$, \\ Jason S. Krumholz ${ }^{6}$, James P. Delgado ${ }^{7}$, Christopher N. Roman ${ }^{1,5}$, Clara Smart ${ }^{5}$, Katherine L.C. \\ Bell $^{2}$, Muhammet Duman ${ }^{8}$, Carter DuVal ${ }^{4}$ \\ ${ }^{1}$ Graduate School of Oceanography, University of Rhode Island, Narragansett, RI 02882, USA \\ ${ }^{2}$ Ocean Exploration Trust, Old Lyme, CT 06371, USA \\ ${ }^{3}$ Department of Classics, Luther College, Decorah, IA 52101, USA \\ ${ }^{4}$ College of Earth, Ocean, and Environment, University of Delaware, Newark, DE 19716, USA \\ ${ }^{5}$ Department of Ocean Engineering, University of Rhode Island, Narragansett, RI 02882, USA \\ ${ }^{6}$ NOAA/NMFS Northeast Fisheries Science Center, Milford, CT 06904, USA \\ ${ }^{7}$ NOAA Office of National Marine Sanctuaries, Silver Spring, MD 20910, USA \\ ${ }^{8}$ Institute of Marine Science and Technology, Dokuz Eylül University, Izmir, Turkey \\ *Corresponding author, mlbrennan@mail.uri.edu \\ Present Address: 215 South Ferry Road, Narragansett, RI 02882
}

Keywords: trawling, shipwrecks, Black Sea, Aegean Sea, artificial reefs, seabed morphology

\begin{abstract}
Bottom trawl fishing presents a severe yet largely unquantified threat to shipwreck sites. Here we present a quantification of damage to sites from the Aegean and Black Seas through high resolution imaging of 45 shipwrecks discovered by the E/V Nautilus expeditions, 2009-2012.
\end{abstract}

These shipwrecks are part of a modern submarine landscape that is heavily damaged by trawls, which also remove sediment and smooth out natural features of the seabed. We quantify the severity of this threat to archaeological sites through repeat visits to one ancient shipwreck and quantify the change to the seabed over a period of eleven months. The results illustrate the benefits of enforced areas of restricted bottom trawling (Marine Protected Areas) to the in situ preservation of shipwreck sites and to natural seabed features and benthic habitats. Careful marine spatial planning and and coordinated management of fishing activity can mitigate this destructive activity. In addition, we counter the claim made by some commercial salvors who 
use trawl damage as an excuse to salvage artifacts from wrecks, further destroying historically significant sites for profit.

\section{Introduction}

The destructive effects of mobile fishing gear towed along the seabed have long been a topic of concern for benthic ecologists (Collie et al., 2000; Jones, 1992; NRC, 2002; Puig et al., 2012), but until recently the alarming rate at which shipwreck sites are destroyed by trawling has been almost entirely overlooked by the maritime archaeology community. As exploration and surveys in deep coastal waters expand, shipwreck sites are frequently discovered to be heavily entangled in fishing nets or broken and scattered by trawl doors and weights (Brennan et al., 2012, 2013; Kingsley, 2010). Extensive trawling in coastal areas have a drastic effect on the benthic environment as it smoothes over and eradicates features of the seabed, including structures like ripples, mesophotic reefs and other soft substrate habitats (Cady, 1973; Dickson et al., 1978; Hall-Spencer and Moore, 2000), as well as reducing the complexity of the seabed (NRC, 2002; Brennan et al., 2012). In a study of trawling impacts on sea scallop habitats on the intercontinental shelf of the Mid-Atlantic Bight, Walker (2013) found areas where the dominant

seabed roughness was composed of dredge furrows. Such large scale restructuring of the seabed morphology has implications for the preservation and interpretation of modern/recent depositional assemblages.

Historic and ancient shipwrecks are both irreplaceable cultural sites and features of the modern seabed that serve as important artificial reef habitats (Walker et al., 2007). Efforts to protect such sites from mobile fishing gear activities have been minimal; even some of the marine protected areas (MPAs) that have been established still allow commercial fishing (US 
Dept. of Commerce, 2010). One of the primary obstacles hindering proper assessment, protection, and management of these underwater cultural resources, however, is sparse documentation of the damage inflicted on wreck sites and the adjoining seabed. The problem is especially acute considering the limited accessibility of deep water to most researchers and resource managers (Brennan and Ballard, 2014). The essential component lacking in this area of research is the thorough documentation of threatened and damaged sites by means of return visits and repeated surveys.

In addition to working toward appropriate management of underwater cultural heritage (UCH), a more comprehensive understanding of mobile fishing gear damage to shipwrecks is imperative for protecting sites targeted for their commercial value. The UNESCO Convention on the Protection of the Underwater Cultural Heritage of 2001 stipulates that in situ preservation of cultural sites should be considered as the first option for management (Maarleveld, 2011). However, the threat that trawl activities present to many shipwreck sites has been used by salvage companies, such as Odyssey Marine Exploration, to justify the commercial salvage and sale of valuable materials from wreck sites for profit (Kingsley, 2010; Pringle, 2013). Here we present an alternative approach to shipwreck site management by documenting not only trawl damage to wreck sites, but also the extent and intensity of trawl scarring on the surrounding seabed in comparison to areas where trawling is prohibited or has not occurred. These results illustrate that effective management and enforcement of trawl restrictions can do much to protect shipwrecks in situ (Brennan et al., 2012). The goals of this research are two-fold: to quantify the damage done to wreck sites and surrounding benthic environment in order to understand and illustrate the actual threat posed by trawling, and to use these data to distance such studies from 
attempts to justify the commercial salvage of wreck sites by showing an alternative solution working toward effective in situ preservation.

The research presented here is the first effort to quantify in detail the extent of trawl damage to a shipwreck site over a short period of time. Ereğli E, one of the oldest deep water shipwrecks found in the Black Sea, is located off the coast of Ereğli, Turkey (ancient Heraclea Pontica) on the southern coast of the Black Sea. It was discovered and mapped in 2011 during an expedition by exploration vessel (E/V) Nautilus. The nine identifiable ceramic types visible on the wreck pinpoint it in the Late Classical or Early Hellenistic era (325-300 B.C.E.) (Brennan et al., 2013). The wreck site exhibits severe damage from trawling, which has broken more than half of the artifacts visible on the surface and ripped up wooden planking that had been preserved under the sediment. These planks include rare evidence of both sewn and mortise-and-tenon joinery, ship construction techniques that are typically not known to be concurrent. Also among the materials wrenched by trawls from their in situ position were human bones, including a femur, a tibia, and teeth. When we returned to the site in 2012, the wreck was found to have been heavily trawled in the intervening eleven months. As a result, the human remains were entirely swept away, the surrounding seabed was smoothed over, most of the other artifacts were either missing, broken further, or displaced, and an estimated $15 \mathrm{~m}^{3}$ of material was removed from the site. The wreck was mapped a second time, providing us with a means to quantify the change to the site caused by trawling since its initial discovery. Ereğli E could have been one of the most significant shipwrecks ever found to date in the Black Sea due to its unique cargo, state of preservation, and human remains, but it has been almost entirely destroyed by trawling. The significance of this wreck now lies in our efforts to document the mode of the site's loss. 
2. Assessing trawl damage to the seabed and ancient shipwrecks

In addition to Ereğli E, 44 other ancient and pre-modern wrecks were located during Nautilus operations in Turkish waters from 2009-2012. In the Aegean and Mediterranean Seas, sites range from large piles of amphoras (two-handled transport jars) to small wreck sites composed of ballast stones and a variety of small artifacts (Brennan et al., 2012). Sites in the Black Sea typically consist of more wood timbers due to the anoxic and suboxic waters that help preserve them (Brennan et al., 2013). However, the majority of these wrecks exhibit some form of damage from trawls, either in the form of broken and scattered ceramic artifacts or wooden components that show clear signs of being ripped apart into a jumbled pile. In the latter case, quantification and even identification or dating of the sites was impossible due to the chaotic condition of the damaged sites. Seventeen of these sites, however, are amphora wrecks, and the trawl damage was quantified by calculating the percentage of broken artifacts visible on each wreck based on photomosaics of each site (see methods described in Brennan et al., 2012). This quantification of damage permits comparisons between wreck sites in a geographical region and in relation to areas of trawl prohibition.

Figure 1 shows a map of the Yalıkavak area of the Bodrum peninsula of Turkey and sidescan sonar survey lines and wrecks located in the area. Plotted here is the intensity of trawl scarring on the seabed and a shaded $2.5 \mathrm{~km}$ boundary from the coast within which trawling is prohibited by Turkish regulations (KKGM, 2006). The extent and intensity of scarring on the seabed ends at this boundary. The scars shown in the sonar image in Figure 1 illustrate the trawlers turning away from this zone. The appearance and morphology of trawl scars on the seabed is well documented (e.g., Walker, 2013; Lucchetti and Sala, 2012; Hall-Spencer and Moore, 2000; Dickson et al., 1978). This sonar image also illustrates the overprinting and thus 
loss of the primary sedimentary bedforms and textural rearrangement of the seabed by repeated trawl scarring. Here the trawlers are seen to adhere to the coastal regulation by maneuvering away from this area.

Shipwrecks found in deeper water farther from the coast also illustrate a general adherence to this restricted trawl zone. For example, shipwrecks found to the south of the Datça peninsula, along the approaches to ancient Knidos, show greater damage from trawling with distance from the coast. The percentage of broken artifacts versus the wreck's distance from the coast is plotted in Figure 2. This graph shows a step function, illustrating that after about $4 \mathrm{~km}$ from shore the area south of Knidos is trawled more heavily, further damaging the wrecks in those waters. Marmaris B, the most heavily damaged wreck found $(62.5 \%$ of its artifacts broken), lies farthest from the coast (Brennan et al., 2012). Other ancient shipwrecks located off Knidos exhibit trawl damage differently. Trawling of the Knidos J site, for example, has exposed the wreck's wooden planking which had previously been preserved beneath the sediment (Figure 3). In addition to the physical damage caused by the trawl here, the exposure of wooden planking that had been preserved beneath the sediment will allow for it to now be deteriorated by wood-boring organisms.

\section{Damage to the seabed}

Shipwreck sites can be viewed not only as time capsules of a moment in history lost to the deep sea, but also as features of the modern submarine landscape that have come into equilibrium with the marine environment, and are today part of the benthic topography (Brennan and Ballard, 2014; Brennan et al., 2012). Research viewing shipwrecks as features of the seabed has been 
effective in documenting the local marine environment and as platforms for time-series type work (e.g., Brennan et al., 2011; Damour et al., 2015; Ruuskanen et al., 2015). Such research potential is destroyed by trawling, as any natural physical or chemical environmental parameters of wrecks are destroyed as trawls scrape the sites away. As shown in Figure 1, areas of extensive trawl damage to the seabed leave a flattened, barren sediment surface that is crisscrossed with scars from frequent trawling. Not only does trawling damage benthic ecosystems and shipwrecks, it also overprints other features of the seabed including bedforms and outcrops, and causes resuspension of sediments that is detrimental to the upper layer of sediment and chemical processes occurring there (e.g., Humborstad et al., 2004; NRC, 2002; Smith et al., 2003). The disturbance and removal of the primary sedimentary structures also destroys potentially important clues about the geomorphological evolution of shipwreck sites and of the recent depositional history of the modern site.

Acoustic classification of the seabed was conducted on the side-scan sonar surveys off Ereğli in 2011 and 2012 with ArcGIS as imagery classification based on the intensity of backscatter returns. The acoustic classes are generally influenced by differences in grain size, roughness, and morphology of the surface sediments (Raineault et al., 2013; Shumchenia and King, 2010). Previous studies have shown that intensive trawling decreases roughness and complexity of the seabed (e.g., Humborstad et al., 2004). Brennan et al. (2012) showed this for the side-scan survey conducted off Yalıkavak, Turkey, shown here in Figure 1. The area of intensive trawling just north of the no trawl zone was classified as its own acoustic class compared to the sediments within this boundary that were unaffected. Figure 4 shows the results of acoustic classification for the surveys off Ereğli, which is dominated by a single class that represents an area of intensive trawling. The second class in the southeastern part of the survey 
grid corresponds to seabed with rocky outcrops where trawling was less, and the third class shows areas where the survey passed over the shelf break. It would normally be expected that classification of a survey such as this would include multiple classes that reflect the seabed's properties including sediment type changing with distance from shore, morphology, and bedforms, and yet here the classification is dominated instead by the intense trawling that has overprinted and erased these features. The only acoustic properties that are classified as different from the main class of trawl scars are in areas where trawling was reduced or lacking due to the shelf break or rocky outcrops. Similarly, this area's shipwrecks all exhibit trawl damage like Ereğli E with the exception of Ereğli D that lies at the shelf break on the northeastern edge of the survey and escaped trawl damage (Brennan et al., 2013).

4. Quantifying trawl damage through repeat microbathymetric surveys The collection of wrecks located in Turkish waters during the Nautilus expeditions provides a large dataset documenting the various states of shipwreck sites damaged by trawls. However, one of the greatest challenges to understanding and quantifying the damage trawling operations have wrought on underwater cultural heritage is prolonged monitoring and repeat site surveys due to limited access to deep water sites. The Ereğli E shipwreck, discovered in 2011 and revisited eleven months later in 2012, is the first time a repeat survey was conducted on an actively trawled shipwreck site. These two surveys, conducted with stereo cameras and multibeam sonar from the Hercules ROV, provide a true quantification of changes made to a wreck site as a result of trawling over the course of one year. A trawl scar is visible in the 2011 map on the western end of the site (Figure 5), strongly suggesting that trawling action over the site prior to its discovery upended and exposed to the surface what were previously buried 
wooden timbers, ceramics, and human remains. Upon our return to the wreck in 2012, there were clear differences in the morphology of the site and the visible artifact assemblage. Very few of the artifacts noted in 2011, especially the human remains and those timbers that revealed both sewn and mortise-and-tenon joinery, were still present on the site. This includes a timber that is visible in the 2011 map to the east of the large artifact mound on the western end of the wreck, which had a rectangular cut notch still preserved. These changes are evident in Figure 5, which shows the bathymetry maps from the 2011 and 2012 surveys, respectively. The 2012 map shows a clear change in relief on the seabed from trawls scraping away sediment and artifacts.

Our analysis of the two microbathymetry surveys of the Ereğli E wreck site provides the first detailed documentation of how an ancient shipwreck site changes morphologically due to repeated strikes by bottom trawl gear. Figure 5 also shows a 3D illustration of the calculated difference between the 2011 and 2012 bathymetry surveys of Ereğli E. White color indicates no change in relief between the two surveys. Red indicates negative change, or material that was removed from the site since 2011 , and blue indicates positive change, or material that has been moved to create positive relief by the time of the 2012 survey. The greatest negative change illustrated by this difference map is over the area of the wreck site itself. The relief of the shipwreck on the seabed provides a greater target for trawl gear to impact than the otherwise relatively flat bottom. Therefore, more of the wreck is scraped away by trawls due to its exposed profile on the seabed, reflected in the red colors in Figure 5. The net volumetric change to the seabed was a loss of $\sim 15 \mathrm{~m}^{3}$ over a spatial area of $\sim 184 \mathrm{~m}^{2}$. Given the intensity of trawl fishing, the implication for overall erosion and sudden transport disturbance to the seabed has a potentially large cumulative effect over the entire shelf setting. This large-scale form of anthropogenic scour dominates any natural current-driven sediment processes along the seabed 
that would normally trap sediment and other materials against the relief of a wreck. This change to the seabed geomorphology therefore masks our ability to characterize the modern depositional environment and posses a challenge to interpretation of the recent and adjoining sedimentary deposits.

The trawl scar at the western end of the site in the 2011 map remains visible in the difference map as blue, showing a negative change in relief around the scar from the sediment at the west end having been scraped away down to the level of the scar, and illustrating the continued removal of material by trawls. The areas of positive relief change (blue) are artifacts that were moved but not removed from the site entirely, with some small changes due to movement of sediment (lighter shades). Some of the displaced artifacts are visible adjacent to spots of dark red negative change, representing the areas from which the artifacts were moved. Areas of the seabed, for example to the southeast of the wreck site, show the seabed smoothed over by trawl nets and chains between surveys, and reflected in the difference map (5b). Finally, the notched timber that was apparently dragged away is shown as a dark red shadow in the center of the wreck in the difference map against lighter red areas of sediment removal, clearly documenting this timber's removal from the site. In addition to material that was removed from the site, both artifact and sediment, a large amount was also displaced within the bounds of the site, illustrated by the blue colors that show small-scale positive change. Based on the two microbathymetry surveys, we can estimate that as much as $15 \mathrm{~m}^{3}$ have been removed from the shipwreck site by trawls between 2011 and 2012, and suggest a rate of damage. The 2012 return to Ereğli E and the repeat high-resolution survey of the site allow us to illustrate for the first time the amount of damage inflicted by trawling on a shipwreck site over a short period of time, calling to attention the imminent threat to underwater cultural heritage. 


\section{Management}

Despite numerous efforts by ecologists and fisheries scientists to mitigate the effects of trawling activities on the seabed, trawling remains one of the greatest threats to benthic ecosystems. Studies documenting the disturbance and degradation of seabed communities call for proper management of and restrictions on trawling operations (De Juan and Demestre, 2012). A primary focus of ecosystem research on this front has been the response of the benthos to towed bottom-fishing gear, the recovery rates of the ecosystem, and overall fishery sustainability, especially as developments in trawl technology enable fishing in deeper waters (Kaiser et al., 2006; Norse et al., 2012; Rooper et al., 2011). However, while benthic ecosystems can recover over time, damage inflicted upon irreplaceable shipwreck sites cannot be repaired (Brennan et al., 2012). The damage we documented to the Ereğli E site illustrates the rate at which underwater cultural heritage is destroyed in heavily trawled areas of seabed. The nearly 50 ancient and premodern shipwrecks located by E/V Nautilus expeditions off the coast of Turkey also speak to the large numbers of potentially undiscovered sites that are threatened in this important maritime cultural landscape. Some of these sites close to land or in areas of steep bathymetry have been spared the heavy damage by trawls, but the majority of them have been found broken and disarticulated (Brennan et al., 2012).

Despite the significant and continual damage inflicted upon these shipwreck sites in Turkish waters, we do not agree with the use of this type of evidence as a justification for the commercial salvage of valuable archaeological sites (Kingsley, 2010; Pringle, 2013). Even in light of this research, we continue to work toward the UNESCO recommendation that in situ preservation is the proper first approach for managing and protecting these sites. This research presents a strong case for establishing MPAs in areas such as those off Sinop and Knidos where 
a large density of cultural sites have been found and documented in regions of heavy trawl activity. Some MPAs around the world do not include trawl restrictions, despite a large presence of maritime heritage sites, such as Stellwagen Bank National Marine Sanctuary (Massachusetts Bay), and protected areas off Turkey would require that specific regulation (US Dept. of Commerce, 2010). However, MPAs can serve multiple purposes. In the Mediterranean, many of the MPAs have been designed primarily to protect benthic habitats and biodiversity, rather than to specifically increase fisheries, which is a common goal of such established areas (Arceo et al., 2013). We have shown that trawlers operating off Turkey deliberately adhere to established, trawl-regulated areas along the coast, indicating that MPAs established in Turkish waters can be enforced.

Management synergy can be achieved in regulating trawling for the protection of shipwrecks, while at the same time protecting habitats and increasing fisheries. Mediterranean capture fisheries have been on a sharp decline since the 1980s, and MPAs specifically designed to increase the fisheries have been proposed and attempted on a small scale (Arceo et al., 2013). Shipwrecks make excellent artificial reefs by providing safe havens for juvenile species to hide, especially the hard substrate offered by the ceramic cargos of ancient shipwrecks (Krumholz and Brennan, 2015). Such reefs can increase local fisheries by the adult fish spillover (Forcada et al., 2009; Harmelin-Vivien et al., 2008; Molloy et al., 2009). As the density of fish individuals increases within an MPA, they will migrate outside into fished areas. Therefore, protecting an area with a high density of cultural sites from trawling can also benefit local fisheries (Krumholz and Brennan, 2015). However, trawling will remove such habitats if targeted for fishing, thus requiring these areas to prohibit trawl activities in order for this management to succeed. We 
propose that this type of management option can do much for preserving shipwreck sites in situ, and without the negative effects of hindering fisheries.

Continued ocean exploration and documentation of maritime cultural heritage is imperative to understanding the threat trawling poses, while also educating the public that commercial salvage is not a desirable option, despite their claims to the contrary. While the seabed lies out of public's view, our surveys show a landscape as desolate as a forest turned into a plowed field that flattens and erases features and habitat on the seabed, be they shipwrecks, sedimentary features, or outcrops. Repeated surveys like the one off Ereğli, Turkey are needed to continue to broaden the documentation of the extent of trawl damage and to best make decisions to effectively manage marine resources of all kinds. Therefore, Ereğli E wreck site serves as a tragic reminder of the damage that trawling can inflict upon not only sites and areas of historical importance, but any unknown and irreplaceable sites hidden from public eye beneath the ocean surface.

Acknowledgements. This work was conducted under Marine Scientific Research permits from the Ministry of Foreign Affairs of the Republic of Turkey numbered 2011/DHGY/7124361 and 2012/DHGY/5852515, and supported by grants from NOAA Office of Ocean Exploration and Research (NA11OAR4600060, NA11OAR4600071, NA08OAR4600534, NA10OAR4600127), the Expedition Council of the National Geographic Society, and the Office of Naval Research (N00014-07-1-0301). The authors wish to thank the Ocean Exploration Trust and the Turkish Ministry of Foreign Affairs, as well as Tufan Turanl, Alexis Catsambis, Heather Pringle, Laurie Bradt, Sandra Witten. 
References:

Arceo, H.O., Cazalet, B., Alino, P.M., Mangialajo, L., Francour, P., 2013. Moving beyond a topdown fisheries management approach in the northwestern Mediterranean: Some lessons from the Philippines. Marine Policy39, 29-42.

Ballard, R.D., Hiebert, F.T., Coleman, D.F., Ward, C., Smith, J.S., Willis, K., Foley, B., Croff, K., Major, C., Torre, F., 2001. Deepwater archaeology of the Black Sea: The 2000 season at Sinop, Turkey. American Journal of Archaeology 105, 607-623.

Brennan, M.L., Ballard, R.D., 2014. Archaeological Oceanography. In Encyclopedia of Natural Resources; Wang, Y.Q., Editor; Taylor \& Francis, New York, pp. 604-608, doi:10.1081/EENRW-120047573.

Brennan, M.L., Ballard, R.D., Roman, C., Bell, K.L.C., Buxton, B., Coleman, D.F., Inglis, G., Koyagasioglu, O., Turanli, T., 2012. Evaluation of the modern submarine landscape off southwestern Turkey through the documentation of ancient shipwreck sites. Continental Shelf Research 43, 55-70, doi:10.1016/j.csr.2012.04.017.

Brennan, M.L., Davis D., Roman, C., Buynevich, I., Catsambis, A., Kofahl, M., Ürkmez, D., Vaughn, J.I., Merrigan, M., Duman, M., 2013. Ocean dynamics and anthropogenic impacts along the southern Black Sea shelf examined by the preservation of premodern shipwrecks.

Continental Shelf Research 53, 89-101, doi:10.1016/j.csr.2012.12.010.

Caddy, J. F. (1973). Underwater observations on tracks of dredges and trawls and some effects of dredging on a scallop ground. Journal of the Fisheries Board of Canada, 30(2), 173-180.

Collie, J.S., Escanerol, G.A., Valentine, P.C., 2000. Photographic evaluation of the impacts of bottom fishing on benthic epifauna. ICES Journal of Marine Science 57, 987-1001.

Damour, Melanie, Robert Church, Daniel Warren, Christopher Horrell, and Leila Hamdan, 2015. Gulf of Mexico Shipwreck Corrosion, Hydrocarbon Exposure, Microbiology, and Archaeology (GOM-SCHEMA) Project: Studying the Effects of a Major Oil Spill on Submerged Cultural Resources. In Marco Meniketti, ed., Underwater Archaeology Proceedings of the 2015 Society for Historical Archaeology Conference, Seattle, WA. Columbus, OH: Advisory Council on Underwater Archaeology, 51-61.

De Juan, S., Demestre, M., 2012. A trawl disturbance indicator to quantify large scale fishing impact on benthic ecosystems. Ecological Indicators 18, 183-190.

Dickson, R. R., Langhorne, D. N., Millner, R. S., and Shreeve, E. G. (1978). An examination of a dredged channel using sector scanning sonar in side-scan mode. Journal du Conseil, 38(1), 41-47. 
Forcada, A., Valle, C., Bonhomme, P., Criquet, G., Cadiou, G., Lenfant, P., SanchezLizaso, J.L., 2009. Effects of habitat spillover from marine protected areas to artisanal fisheries. Marine Ecology Progress Series 379, 197-211.

Hall-Spencer, J. M., and Moore, P. G. (2000). Scallop dredging has profound, long-term impacts on maerl habitats. ICES Journal of Marine Science: Journal du Conseil, 57(5), 1407-1415.

Harmelin-Vivien, M., Le Direach, L., Bayle-Sempere, J., Charbonnel, E., GarciaCharton, J.A., Ody, D., Perez-Ruzafa, A., Renones, O., Sanchez-Jerez, P., Valle, C., 2008. Gradients of abundance and biomass across reserve boundaries in six Mediterranean marine protected areas: Evidence of fish spillover? Biological Conservation 141, 1829-1839.

Jones, J.B. 1992. Environmental impact of trawling on the seabed: a review. New Zealand Journal of Marine and Freshwater Research 26, 59-67.

Kaiser, M.J., Clarke, K.R., Hinz, H., Austen, M.C.V., Somerfield, P.J., Karakassis, I., 2006. Global analysis of response and recovery of benthic biota to fishing. Marine Ecology Progress Series 311, 1-14.

Kingsley, S.A., 2010. Deep-sea fishing impacts on the shipwrecks of the English Channel and western approaches. In Oceans Odyssey: Deep-Sea Shipwrecks in the English Channel, Straits of Gibraltar, and Atlantic Ocean, eds. Greg Stemm and Sean Kingsley, 191-233.

Koruma ve Kontrol Genel Müdürlüğü (KKGM), 2006. Circular No. 37/1 of 2006-2008 Fishing Year Regulating Commercial Fishing in Seas and Inland Waters. Koruma ve Kontrol Genel Müdürlüğü, Ankara, Turkey.

$<$ http://www.kkgm.gov.tr/regulation/circular/37-1.html>. Accessed December 2009.

Krumholz, J., Brennan, M.L., 2015. Fishing for common ground: Investigations of the impact of trawling on ancient shipwreck sites uncovers a potential for management synergy. Marine Policy 61, 127-133.

Lucchetti, A., Sala, A., 2012. Impact and performance of Mediterranean fishing gear by side-scan sonar technology. Canadian Journal of Fisheries and Aquatic Sciences 69, 1806-1816.

Maarleveld, T.J., 2011. Open letter to Dr. Sean Kingsley Wreck Watch International regarding his questionnaire on in situ preservation. Journal of Maritime Archaeology 6, 107-111.

Molloy, P.P., McLean, I.B., Cote, I.M., 2009. Effects of marine reserve age on fish populations: a global meta-analysis. Journal of Applied Ecology46, 743-751. 
National Research Council (NRC), 2002. Effects of Trawling \& Dredging on Seafloor Habitat. National Academy Press, Washington, D.C.

Norse, E.A., Brooke, S., Cheung, W.W.L., Clark, M.R., Ekeland, I., Froese, R., Gjerde, K.M., Haedrich, R.L., Heppell, S.S., Morato, T., Morgan, L.E., Pauly, D., Sumaila, R., Watson, R., 2012. Sustainability of deep-sea fisheries. Marine Policy 36, 307-320.

Pringle H., 2013. Troubled waters for ancient shipwrecks. Science 340, 802-807.

Puig, P., Canals, M., Company, J.B., Martin, J., Amblas, D., Lastras, G., Palanques, A., Calafat, A.M., 2012. Ploughing the deep sea floor. Nature 489, 286-289.

Raineault, N. A., Trembanis, A. C., Miller, D. C., and Capone, V. (2013). Interannual changes in seafloor surficial geology at an artificial reef site on the inner continental shelf. Continental Shelf Research 58 (2013) 67-78

Rooper, C.N., Wilkins, M.E., Rose, C.S., Coon, C., 2011. Modeling the impacts of bottom trawling and the subsequent recovery rates of sponges and corals in the Aleutian Islands, Alaska. Continental Shelf Research 31, 1827-1834.

Ruuskanen, A.T., P. Kraufvelin, R. Alvik, E.R. Díaz, J. Honkonen, J. Kanerva, K. Karell, P. Kekäläinen, J. Lappalainen, R. Mikkola, T. Mustasaari, N. Nappu, A. Nieminen, J. Roininen, K. Svahnbäck, 2015. Benthic conditions around a historic shipwreck: Vrouw Maria (1771) in the northern Baltic proper. Continental Shelf Research 98, 1-12.

Shumchenia, E.J. and King, J.W., 2010. Comparison of methods for integrating biological and physical data for marine habitat mapping and classification. Continental Shelf Research 30, 1717-1729.

Smith, C.J., Rumohr, H., Karakassis, I., Papadopoulou, K.-N., 2003. Analysing the impact of bottom trawls on sedimentary seabeds with sediment profile imagery. Journal of Experimental Marine Biology and Ecology 285-286, 479-496.

U.S. Department of Commerce. National Oceanic and Atmospheric Administration. Office of National Marine Sanctuaries. 2010. Stellwagen Bank National Marine Sanctuary Final Management Plan and Environmental Assessment. Silver Spring, MD.

Walker, J.H., (2013). Abundance and size of the sea scallop population in the MidAtlantic Bight (Master's thesis). University of Delaware, Newark, DE.

Walker S., Schlacher, T., Schlacher-Hoenlinger, M., 2007. Spatial heterogeneity of epibenthos on artificial reefs: fouling communities in the early stages of colonization on an East Australian shipwreck. Marine Ecology 28, 435-445. 


\section{Figure Captions}

Figure 1 | Map of side-scan sonar survey off Yalıkavak, Turkey. The map shows trawl scar counts as circles, illustrating a swath of higher intensity adjacent to the $2.5 \mathrm{~km}$ boundary from the coast. The inset image is a screenshot of the side-scan sonar data showing the trawl scars turning away from the boundary as fishermen adhere to this zone (Brennan et al., 2012).

Figure 2 | Bivariate graph showing a step function of trawl damage on shipwreck sites with distance from coast (after Krumholz and Brennan, 2015).

Figure 3 | Images of Knidos J shipwreck site showing a trawl scar through the middle of the wreck a, Photomosaic of the site showing a trawl scar that ripped up planking preserved beneath the sediment and $\mathbf{b}$, close-up image of trawl scar on Knidos J.

Figure 4 | Map of the side-scan sonar survey west of Ereğli, Turkey combining the 2011 and 2012 data. Acoustic classes are shown based on the intensity of backscatter returns. This classification shows a dominant class caused by the heavy trawling across most of this area.

Figure 5 | a) Microbathymetry maps showing the surveys of Ereğli E in 2011 and 2012 plotted over the map showing the difference between them, while b) shows the calculated microbathymetric difference between the 2011 and 2012 surveys and change in relief across the site due to bottom trawl damage. Red shows negative change at the site while blue indicates areas of positive change, and white shows no change. " $\mathrm{A}$ " marks the trawl scar and "B" marks the notched timber, both features from the 2011 survey, missing in 2012, and visible in the difference map. 


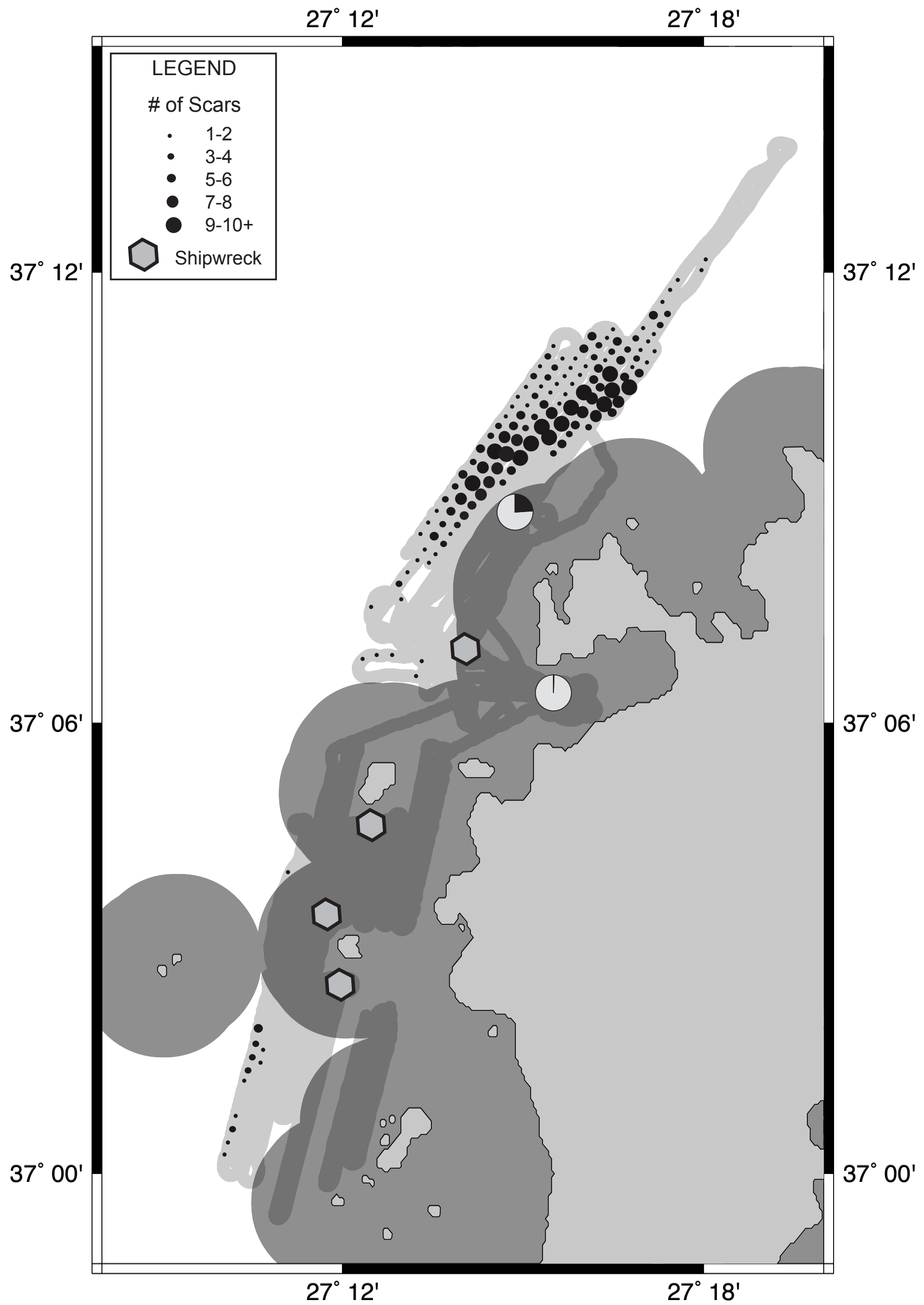




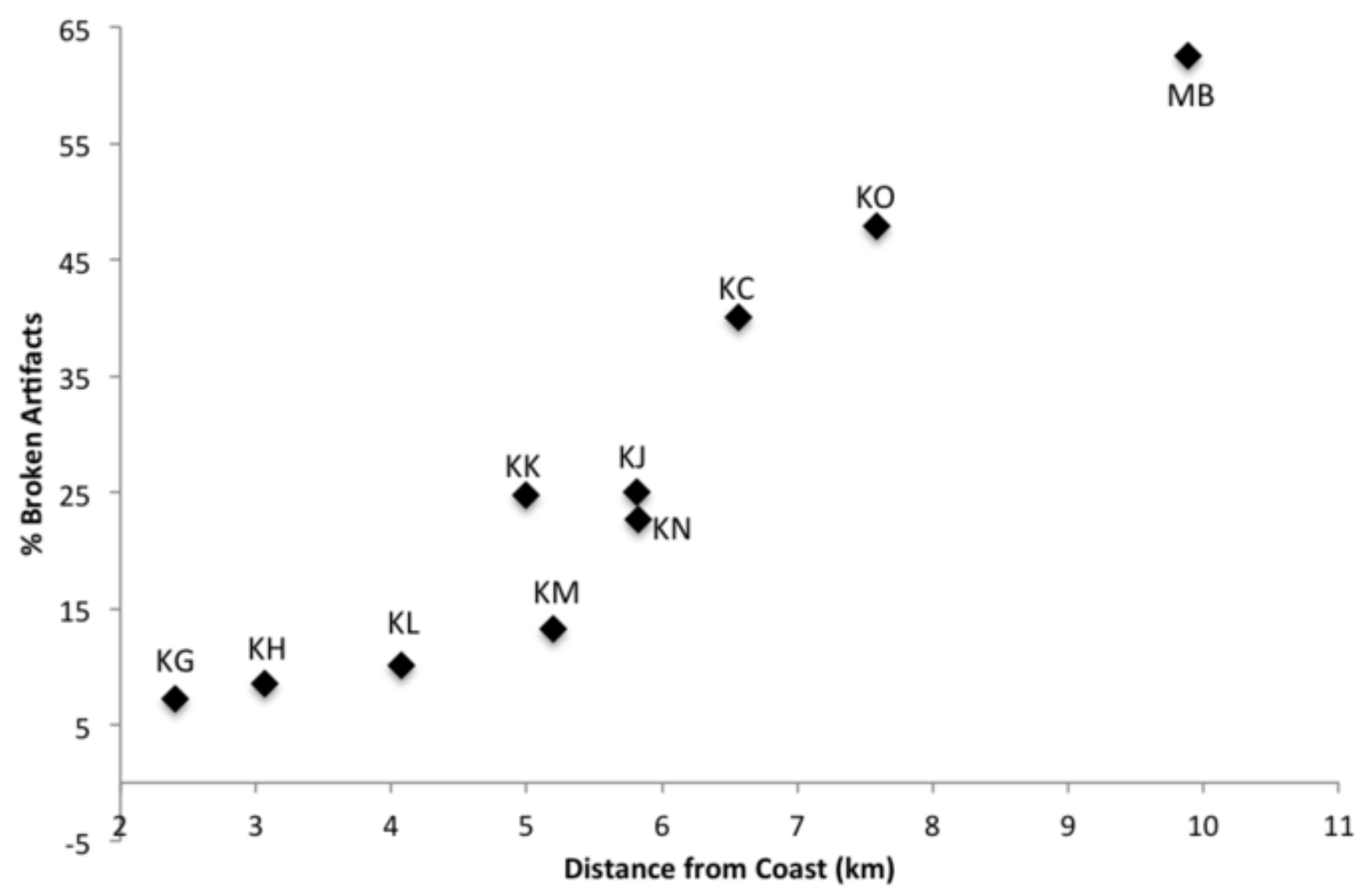




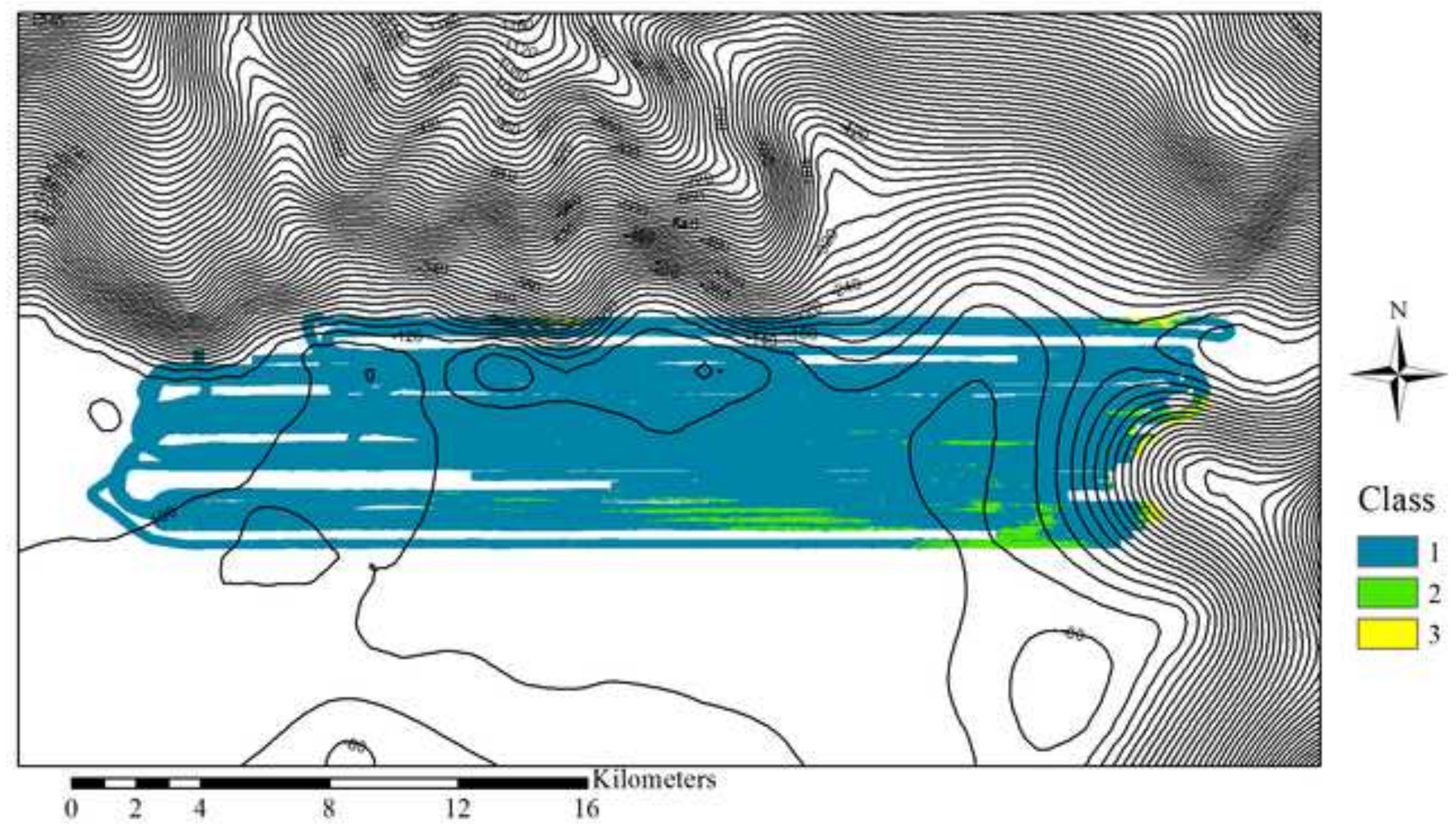



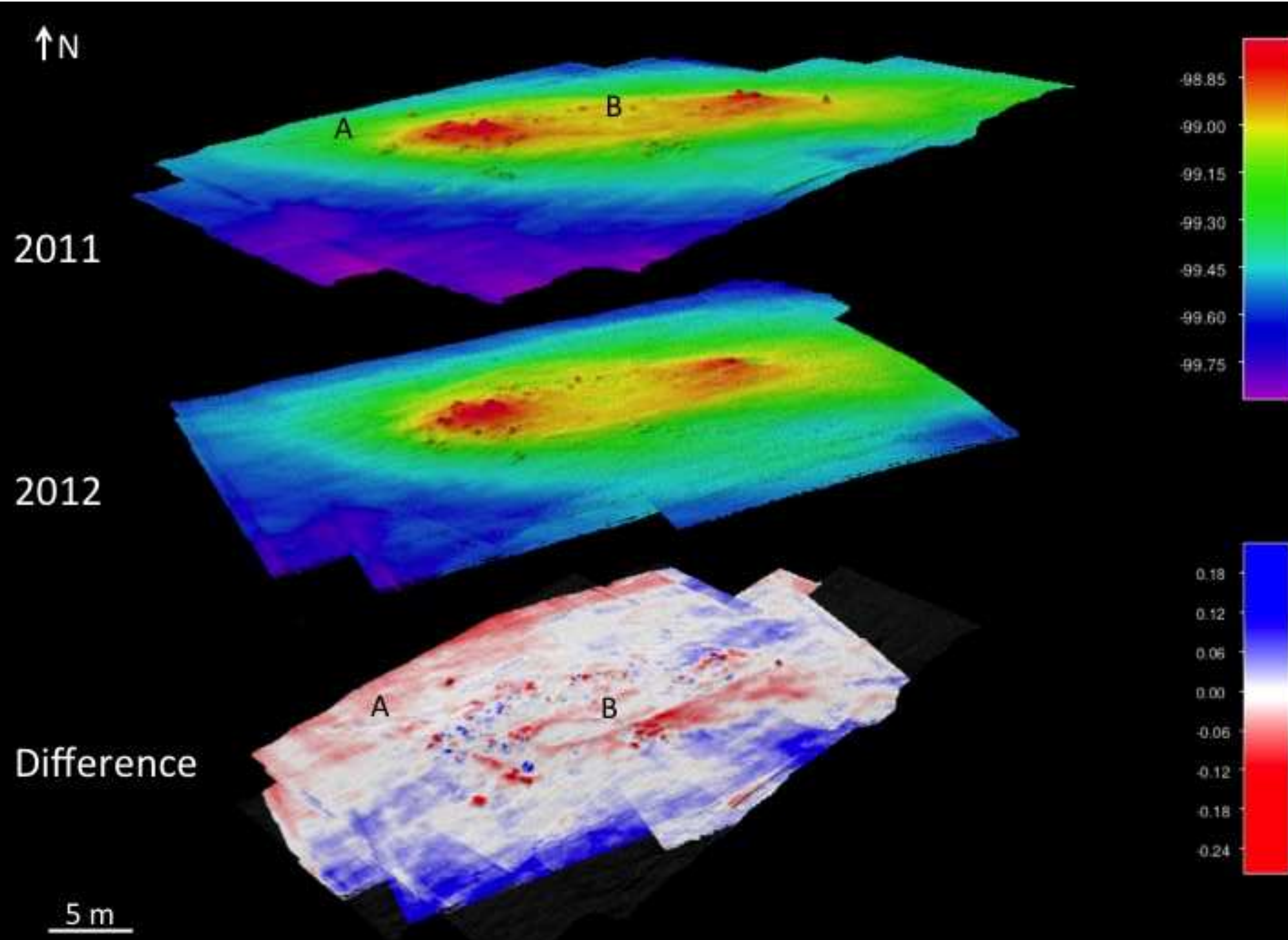